\title{
Interactions of Uranium and Neptunium with Cementitious Materials Studied by XAFS
}

\author{
E.R. Sylwester, P.G. Allen, P. Zhao, B.E. Viani
}

This article was submitted to 1999 Materials Research Society Fall Meeting, November 29December 3, 1999, Boston, MA

\section{November 3, 1999}

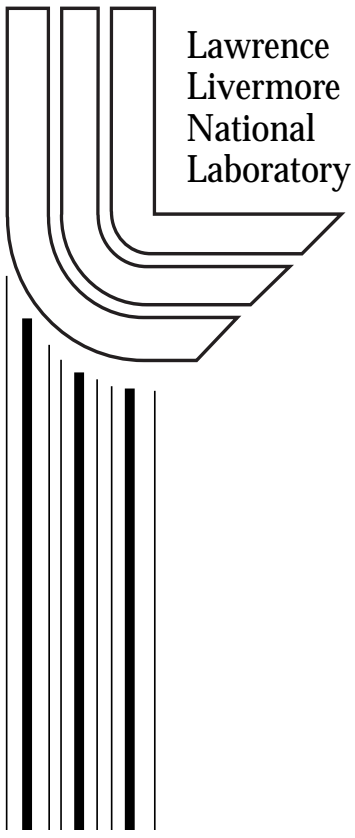




\section{DISCLAIMER}

This document was prepared as an account of work sponsored by an agency of the United States Government. Neither the United States Government nor the University of California nor any of their employees, makes any warranty, express or implied, or assumes any legal liability or responsibility for the accuracy, completeness, or usefulness of any information, apparatus, product, or process disclosed, or represents that its use would not infringe privately owned rights. Reference herein to any specific commercial product, process, or service by trade name, trademark, manufacturer, or otherwise, does not necessarily constitute or imply its endorsement, recommendation, or favoring by the United States Government or the University of California. The views and opinions of authors expressed herein do not necessarily state or reflect those of the United States Government or the University of California, and shall not be used for advertising or product endorsement purposes.

This is a preprint of a paper intended for publication in a journal or proceedings. Since changes may be made before publication, this preprint is made available with the understanding that it will not be cited or reproduced without the permission of the author.

This report has been reproduced

directly from the best available copy.

Available to DOE and DOE contractors from the

Office of Scientific and Technical Information

P.O. Box 62, Oak Ridge, TN 37831

Prices available from (423) 576-8401

http://apollo.osti.gov/bridge/

Available to the public from the

National Technical Information Service

U.S. Department of Commerce

5285 Port Royal Rd.,

Springfield, VA 22161

http://www.ntis.gov/

OR

Lawrence Livermore National Laboratory

Technical Information Department's Digital Library

http://www.llnl.gov/tid/Library.html 


\title{
INTERACTIONS OF URANIUM AND NEPTUNIUM WITH CEMENTITIOUS MATERIALS STUDIED BY XAFS.
}

\author{
E. R. SYLWESTER ${ }^{1}$, P. G. ALLEN ${ }^{1}$, P. ZHAO ${ }^{1}$, B. E. VIANI ${ }^{2}$ \\ ${ }^{1}$ Glenn T. Seaborg Institute for Transactinium Science, Lawrence Livermore National \\ Laboratory, P.O. Box 808, MS L-231, Livermore, CA 94551, sylwester1@1lnl.gov \\ ${ }^{2}$ Geosciences \& Environmental Technologies Division, Lawrence Livermore National \\ Laboratory
}

\begin{abstract}
We have investigated the interaction of $\mathrm{U}(\mathrm{VI})$ and $\mathrm{Np}(\mathrm{V})$ actinide ions with cementitious materials that are relevant to nuclear waste repositories using X-Ray Absorption Fine Structure (XAFS) Spectroscopy. The actinide ions were individually loaded onto untreated as well as hydrothermally treated cements. The mixtures were then equilibrated at varying $\mathrm{pH}$ 's for a period of approximately 6 months.

In all cases uranium was introduced in the form of aqueous uranyl ion, $\mathrm{UO}_{2}{ }^{2+}$, and was observed to remain in this form based on the Near Edge (XANES) spectra. The uranium samples show evidence of interactions with both treated and untreated cements at all pH's, with uranyl interacting with the cement mineral phases (i.e., $\mathrm{SiO}_{2}$ ) through an inner-sphere mechanism where oxygen atoms in the equatorial plane of the uranyl ion are shared with the mineral surface. In contact with the hydrothermally treated cement, the uranyl ions are also observed to form oligomeric species, proving that hydrothermal treatment of the concrete has a significant effect on the structural bonding characteristics of uranyl on the concrete.

Neptunium was introduced as the neptunyl ion, $\mathrm{NpO}_{2}{ }^{+}$, and was observed to undergo a reduction from $\mathrm{Np}(\mathrm{V})$ to $\mathrm{Np}(\mathrm{IV})$. Percent reduction was calculated from both component analysis of the XANES region and by curve fitting to the EXAFS region. Results from both methods were in good agreement and showed ca. $15 \%$ of $\mathrm{Np}(\mathrm{V})$ is reduced to $\mathrm{Np}(\mathrm{IV})$ in the fresh sample. In comparison, the other samples showed higher reduction rates of between $40 \%$ and $65 \%$. Reduction was thus observed to occur over a relatively slow time scale based on XAFS data collected from a "fresh" sample (aged for 1 month). No Np-Np interactions were observed in the EXAFS spectra which makes surface precipitation of $\mathrm{Np}^{4+}$ phases an unlikely mechanism for sorption.
\end{abstract}

\section{INTRODUCTION}

Cementitious materials comprise a large fraction of the near-field environment of US high-level nuclear waste repositories, and interactions between waste radioisotopes and concrete can be expected to occur after breaching of primary containment vessels but before migration to the far field environment. The ability of concrete to sorb relevant radionuclides is thus important in determining the rate at which these waste products will enter the far field. Concrete has previously been shown to be a strong sorber of some actinides $[1,2]$, however, it is expected that during the storage times of $>10,000$ years the infrastructure of these repositories will be subjected to high temperatures caused by radiative heating, as well as wide variations in humidity. These conditions may alter the the chemical or structural characteristics of the concrete and so alter the materials' ability to sorb waste radionuclides that have been released from their primary container. 
In order to determine possible temperature and humidity effects on the sorptive properties of concrete, samples of portland cement were hydrothermally heated at $200{ }^{\circ} \mathrm{C}$ for 8 months to produce a "treated" concrete. X-Ray Absorption Fine Structure (XAFS) was then used to study samples of Uranium and Neptunium sorbed onto both treated and untreated concreted in order to determine changes in the speciation (oxidation state and structure) of the radionuclides. Experiments were conducted as a function of $\mathrm{pH}$ within the range expected to occur in the field [3] and as a function of time in order to determine possible aging effects.

\section{EXPERIMENT}

\section{$\underline{\text { Sample Preparation }}$}

Samples of crushed $(<53 \mu \mathrm{m})$ treated and untreated concrete were reacted with $0.01 \mathrm{M}$ $\mathrm{NaCl}$ containing $\mathrm{U}$ or $\mathrm{Np}$ at mass/volume ratio of $0.4 \mathrm{~g} / \mathrm{L}$ at room temperature $\left(23 \pm 2{ }^{\circ} \mathrm{C}\right)$. The initial oxidation states of the radionuclides in solution were confirmed using UV/VIS spectrometry prior to sample preparation. Samples were then equilibrated for ca. 5-6 months. After aging, the aqueous phase was drawn off and the remaining wet paste samples packaged for XAFS analysis. One "fresh" sample each of U(VI) and Np(V) sorbed to treated concrete at $\mathrm{pH} 10.2$ was also prepared with one month equilibration time prior to XAFS measurement.

\section{$\underline{\text { XAS Spectroscopy }}$}

$\mathrm{L}_{\mathrm{III}}$-edge X-ray absorption fine structure (XAFS) spectra were collected for $\mathrm{U}$ and $\mathrm{Np}$ sorption samples at the Stanford Synchrotron Radiation Laboratory (SSRL). The samples were studied on beamline 4-1, using a Si(220) double-crystal monochromator. All spectra were collected at room temperature, either in transmission mode using argonfilled ionization chambers or in fluorescence mode using a Ge solid state detector developed at Lawrence Berkeley National Laboratory[4]. The spectra were calibrated by simultaneous measurement of $\mathrm{UO}_{2}$ or $\mathrm{NpO}_{2}$ references, defining the first inflection point at $17166.0 \mathrm{eV}$ and $17606.2 \mathrm{eV}$ for the $\mathrm{U}$ and $\mathrm{Np} \mathrm{L} \mathrm{L}_{\mathrm{III}}$-edges, respectively.

The XANES and EXAFS data were extracted from the raw absorption spectra by standard methods described elsewhere [5] using a suite of programs, EXAFSPAK, developed by G. George of SSRL. Nonlinear least-squares curve fitting analysis was performed using EXAFSPAK to fit the raw $\mathrm{k}^{3}$-weighted data. Modeling of the back scattering phases and amplitudes of the individual neighboring atoms was based on FEFF7.2 [6]. The input files for FEFF7.2 were prepared using the structural modeling code ATOMS 2.46b [7]. All of the modeled $\mathrm{UO}_{2}{ }^{2+}$ and $\mathrm{NpO}_{2}{ }^{+}$interactions were derived from FEFF7.2 single or multiple scattering paths (SS or MS) calculated for the model compound $\alpha-\mathrm{UO}_{2}(\mathrm{OH})_{2}[8]$. Microsoft EXCEL ${ }^{\mathrm{TM}}$ was used to perform principal component analysis (PCA) on the spectra using standard methodology [9]. The relative contributions from the two oxidation states present in the $\mathrm{Np} \mathrm{L}_{\mathrm{III}}$ XANES spectra were determined with nonlinear least-squares curve fitting using the program PEAKFIT $^{\mathrm{TM}}$ and data based on XANES spectra of pure $\mathrm{Np}^{4+}$ and $\mathrm{NpO}_{2}^{+}$standards. 


\section{RESULTS}

\section{$\underline{\text { Uranium }}$}

The normalized $\mathrm{U}_{\mathrm{III}}$-edges for all samples are shown in Figure 1. All samples were observed to have a primary absorption peak at $17.17 \mathrm{keV}$ and a high energy shoulder at $17.18 \mathrm{keV}$. Both of these features have previously been shown to be indicative of the $\mathrm{UO}_{2}{ }^{2+}$ moeity [10], with the primary absorption peak associated with the $2 \mathrm{p}_{3 / 2} \rightarrow 6 \mathrm{~d}$ transition and the shoulder associated with MS resonances from the linear uranyl [O-U$\mathrm{O}]^{2+}$ structure.

Figure 2 shows the raw $\mathrm{k}^{3}$-weighted EXAFS data and fourier transforms (FTs) for all samples along with the corresponding nonlinear least-squares fits over the k-range 3-13. Table I gives the coordination numbers $(\mathrm{N})$, bond lengths $(\mathrm{R})$, and Debye-Waller disorder factors $\left(\sigma^{2}\right)$ calculated for all fits shown in Figure 2. There is a clear difference in the raw spectra between the aged samples on treated concrete and the aged samples on untreated concrete. Both are dominated in the low-k region by a low frequency oscillation arising from backscattering of the uranyl oxygen atoms. Spectra of the samples equilibrated on treated concrete have an additional high frequency oscillation that appears at $\mathrm{k} \sim 9$, which can be attributed to the presence of larger, more distant backscatterers (i.e. uranium).

These features are also reflected in the fourier transformed (FT) spectra. The Fourier transforms represent a pseudo-radial distribution function of the uranium near-neighbor environment, where peaks representing the near neighbor atoms appear at lower $\mathrm{R}$ values relative to their true distance from the central atom depending on the phase shift of the backscattering atom. All of the FT spectra show the preservation of the uranyl structure indicated by the presence of a U-O peak at $1.3 \AA$. All samples also show a split equatorial shell (see also Table I). This bond heterogeneity is consistent with surface adsorption and/or precipitate formation. The samples equilibrated on treated concrete also show a U-U interaction at $3.96 \AA$ indicative of oligomer formation or surface precipitation, while no such shell was observed in any of the untreated concrete samples.

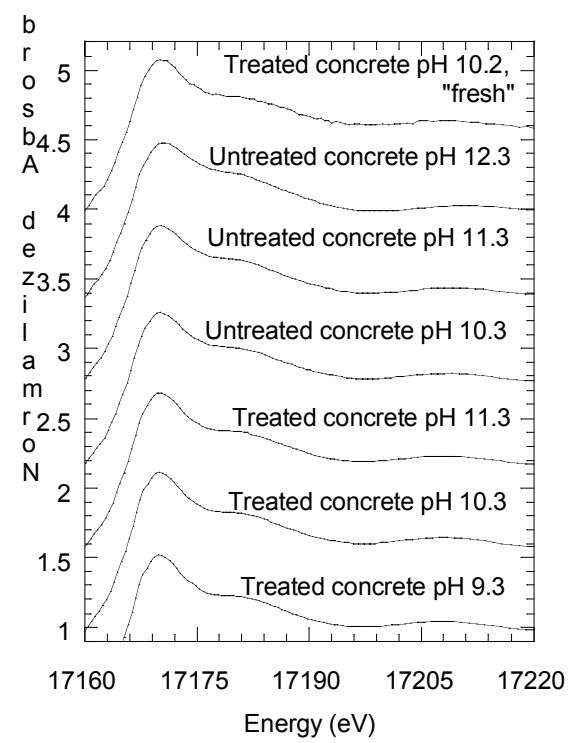

Figure 1: Normalized $\mathrm{U}_{\mathrm{III}}$-edges for samples on treated and untreated concrete. 


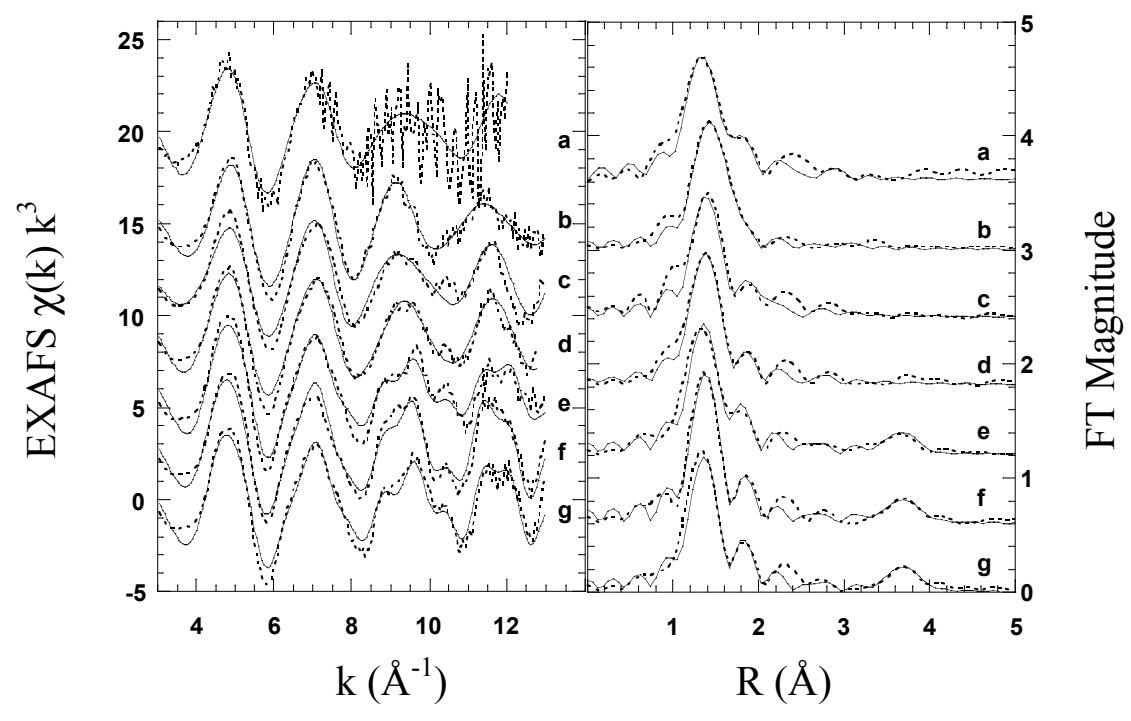

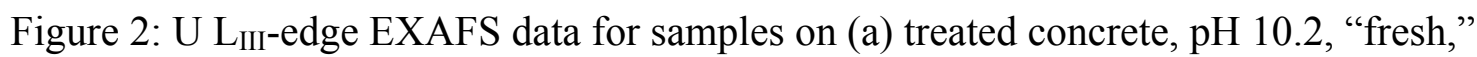
(b) untreated concrete, $\mathrm{pH}$ 12.3, (c) untreated concrete, $\mathrm{pH} 11.3$, (d) untreated concrete, $\mathrm{pH}$ 10.3, (e) treated concrete, $\mathrm{pH}$ 11.3, (f) treated concrete, $\mathrm{pH} \mathrm{10.3,} \mathrm{(g)} \mathrm{treated} \mathrm{concrete,}$ $\mathrm{pH}$ 9.3. The dashed line is the experimental data, and the solid line represents the best theoretical fit to the data. LEFT: raw $\mathrm{k}^{3}$-weighted data. RIGHT: Fourier transforms.

Table I. U EXAFS curve-fitting results.

\begin{tabular}{|c|c|c|c|c|}
\hline Sample & Shell & $\mathrm{N}^{\mathrm{a}}$ & $\mathrm{R}(\AA)^{\mathrm{a}}$ & $\sigma^{2}\left(\AA^{2}\right)^{b}$ \\
\hline \multirow[t]{4}{*}{ Treated concrete, $\mathrm{pH} 9.3$} & $\mathrm{U}-\mathrm{O}_{\mathrm{ax}}$ & 2.00 & 1.81 & 0.00201 \\
\hline & $\mathrm{U}-\mathrm{O}_{\mathrm{eq} 1}$ & 4.33 & 2.30 & 0.00776 \\
\hline & $\mathrm{U}-\mathrm{O}_{\mathrm{eq} 2}$ & 1.82 & 2.48 & 0.00776 \\
\hline & U-U & 0.64 & 3.96 & 0.00076 \\
\hline \multirow{4}{*}{ Treated concrete, $\mathrm{pH} 10.3$} & $\mathrm{U}-\mathrm{O}_{\mathrm{ax}}$ & 2.00 & 1.82 & 0.00115 \\
\hline & $\mathrm{U}-\mathrm{O}_{\mathrm{eq} 1}$ & 3.38 & 2.28 & 0.00606 \\
\hline & $\mathrm{U}-\mathrm{O}_{\mathrm{eq} 2}$ & 2.22 & 2.44 & 0.00606 \\
\hline & U-U & 1.07 & 3.96 & 0.00338 \\
\hline \multirow[t]{4}{*}{ Treated concrete, $\mathrm{pH} 11.3$} & $\mathrm{U}-\mathrm{O}_{\mathrm{ax}}$ & 2.00 & 1.81 & 0.00268 \\
\hline & $\mathrm{U}-\mathrm{O}_{\mathrm{eq} 1}$ & 2.90 & 2.26 & 0.00330 \\
\hline & $\mathrm{U}-\mathrm{O}_{\mathrm{eq} 2}$ & 2.16 & 2.42 & 0.00330 \\
\hline & U-U & 1.51 & 3.96 & 0.00603 \\
\hline \multirow[t]{3}{*}{ Untreated concrete, $\mathrm{pH} 10.3$} & $\mathrm{U}-\mathrm{O}_{\mathrm{ax}}$ & 2.00 & 1.82 & 0.00184 \\
\hline & $\mathrm{U}-\mathrm{O}_{\mathrm{eq} 1}$ & 3.33 & 2.28 & 0.00687 \\
\hline & $\mathrm{U}-\mathrm{O}_{\mathrm{eq} 2}$ & 1.70 & 2.45 & 0.00687 \\
\hline \multirow[t]{3}{*}{ Untreated concrete, $\mathrm{pH} 11.3$} & $\mathrm{U}-\mathrm{O}_{\mathrm{ax}}$ & 2.00 & 1.83 & 0.00242 \\
\hline & $\mathrm{U}-\mathrm{O}_{\mathrm{eq} 1}$ & 4.56 & 2.29 & 0.00967 \\
\hline & $\mathrm{U}-\mathrm{O}_{\mathrm{eq} 2}$ & 1.36 & 2.53 & 0.00967 \\
\hline \multirow[t]{3}{*}{ Untreated concrete, $\mathrm{pH} 12.3$} & $\mathrm{U}-\mathrm{O}_{\mathrm{ax}}$ & 2.00 & 1.83 & 0.00216 \\
\hline & $\mathrm{U}-\mathrm{O}_{\mathrm{eq} 1}$ & 2.54 & 2.23 & 0.00163 \\
\hline & $\mathrm{U}-\mathrm{O}_{\mathrm{eq} 2}$ & 1.44 & 2.39 & 0.00163 \\
\hline \multirow{3}{*}{$\begin{array}{l}\text { "Fresh," treated concrete, } \\
\text { pH } 10.3\end{array}$} & $\mathrm{U}-\mathrm{O}_{\mathrm{ax}}$ & 2.00 & 1.81 & 0.00255 \\
\hline & $\mathrm{U}-\mathrm{O}_{\mathrm{eq} 1}$ & 3.40 & 2.30 & 0.00418 \\
\hline & $\mathrm{U}-\mathrm{O}_{\mathrm{eq} 2}$ & 1.69 & 2.49 & 0.00418 \\
\hline
\end{tabular}

${ }^{a}$ The $95 \%$ confidence limits for the bond lengths $(\mathrm{R})$ and coordination numbers $(\mathrm{N})$ for each shell are: $\mathrm{U}$ $\mathrm{O}_{\mathrm{ax}}: \pm 0.001 \AA ; \mathrm{U}^{-} \mathrm{O}_{\mathrm{eq} 1}: \pm 0.003 \AA$ and \pm 0.3 ; U-O $\mathrm{O}_{\mathrm{eq} 2}: \pm 0.01 \AA$ and \pm 0.2 ; U-U $\mathrm{U}_{(1-3)}: \pm 0.005 \AA$ and \pm 0.3 , respectively.

${ }^{b}$ Debye-Waller factors for $\mathrm{U}-\mathrm{O}_{\mathrm{eq} 1}$ and $\mathrm{U}-\mathrm{O}_{\mathrm{eq} 2}$ were linked in the fits. 


\section{$\underline{\text { Neptunium }}$}

Figure 3 shows the normalized $\mathrm{Np} \mathrm{L}_{\mathrm{III}}$-edges for three representative samples; the "fresh" sample on treated concrete at $\mathrm{pH} 10.2$, and equilibrated samples on treated concrete at $\mathrm{pH} 9.3$ and untreated concrete at $\mathrm{pH}$ 10.3. Also shown for comparison are absorption spectra for $\mathrm{NpO}_{2}{ }^{+}$and $\mathrm{NpO}_{2}$ reference compounds. The experimental samples initially appeared to contain a mix of these oxidation states. PCA analysis confirmed the presence of two components and target testing on four spectra representing the $\mathrm{Np} 3+$, $4+, 5+$, and $6+$ oxidation states resulted in a positive fit for $\mathrm{Np}^{4+}$ and $\mathrm{NpO}_{2}{ }^{+}$, and a negative fit for $\mathrm{Np}^{3+}$ and $\mathrm{NpO}_{2}{ }^{2+}$. The percentage of $\mathrm{NpO}_{2}{ }^{+}$was subsequently determined with PEAKFIT using linear combination least-squares fitting of pure $\mathrm{Np}^{4+}$ and $\mathrm{NpO}_{2}^{+}$ absorption spectra to the sample spectra. These results are shown in Table II. Reduction to the $\mathrm{Np}(\mathrm{IV})$ state was $\sim 15 \%$ in the "fresh" sample and $\sim 50 \%$ in the other samples. No correlation was observed between $\%$ reduction and $\mathrm{pH}$ or hydrothermal treatment.

The $\mathrm{Np} \mathrm{L}_{\text {III }}$ raw $\mathrm{k}^{3}$-weighted EXAFS and FT spectra are shown in Figure 4. Due to the short k-range of the EXAFS, the FTs show a single peak containing interactions from axial and equatorial O's of $\mathrm{NpO}_{2}{ }^{+}$as well as $\mathrm{Np}^{4+}-\mathrm{O}$ interactions. This FT peak moves to higher $\mathrm{R}$ as a function of sample equilibration time indicating a change in the $\mathrm{Np}(\mathrm{V}): \mathrm{Np}(\mathrm{IV})$ ratio with longer equilibration times. Curve fits were performed using the axial Np(V)-O shell expected to occur at $\sim 1.85 \AA$ and a Np-O shell at $\sim 2.4 \AA$ representing a combination of equatorial oxygens bonded to $\mathrm{Np}(\mathrm{V})$ and oxygens bonded to $\mathrm{Np}(\mathrm{IV})$.

To compare the quantitative XANES results with the analysis of the EXAFS, the percent $\mathrm{Np}(\mathrm{V})$ was calculated based on the coordination number of the $\mathrm{Np}(\mathrm{V})-\mathrm{O}_{\mathrm{ax}}$ shell. The results agree within error for six of the seven samples and confirm that reduction is correlated to equilibrium time but not $\mathrm{pH}$ or hydrothermal treatment.

Precipitation of $\mathrm{Np}$ (IV) mixed oxides has been proposed as an alternate mechanism to sorption for Np partitioning to the solid phase. However our EXAFS spectra show no evidence of $\mathrm{Np}$ precipitates, which would be indicated by $\mathrm{Np}-\mathrm{Np}$ interaction at $\mathrm{R} \sim 4 \AA$.

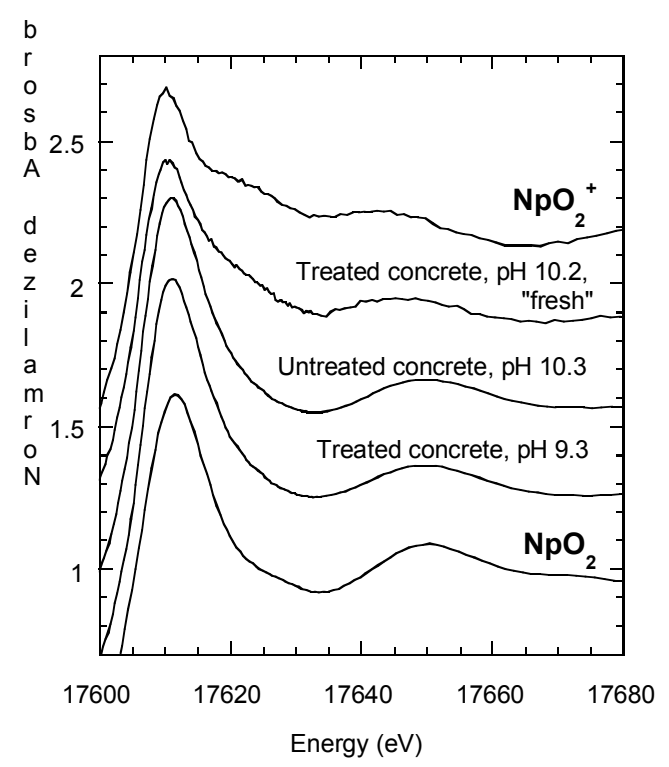

Figure 3: Comparison of the normalized Np $\mathrm{L}_{\mathrm{III}} \mathrm{XANES}$ for three of the samples with XANES spectra for pure $\mathrm{NpO}_{2}$ and $\mathrm{NpO}_{2}^{+}$. 


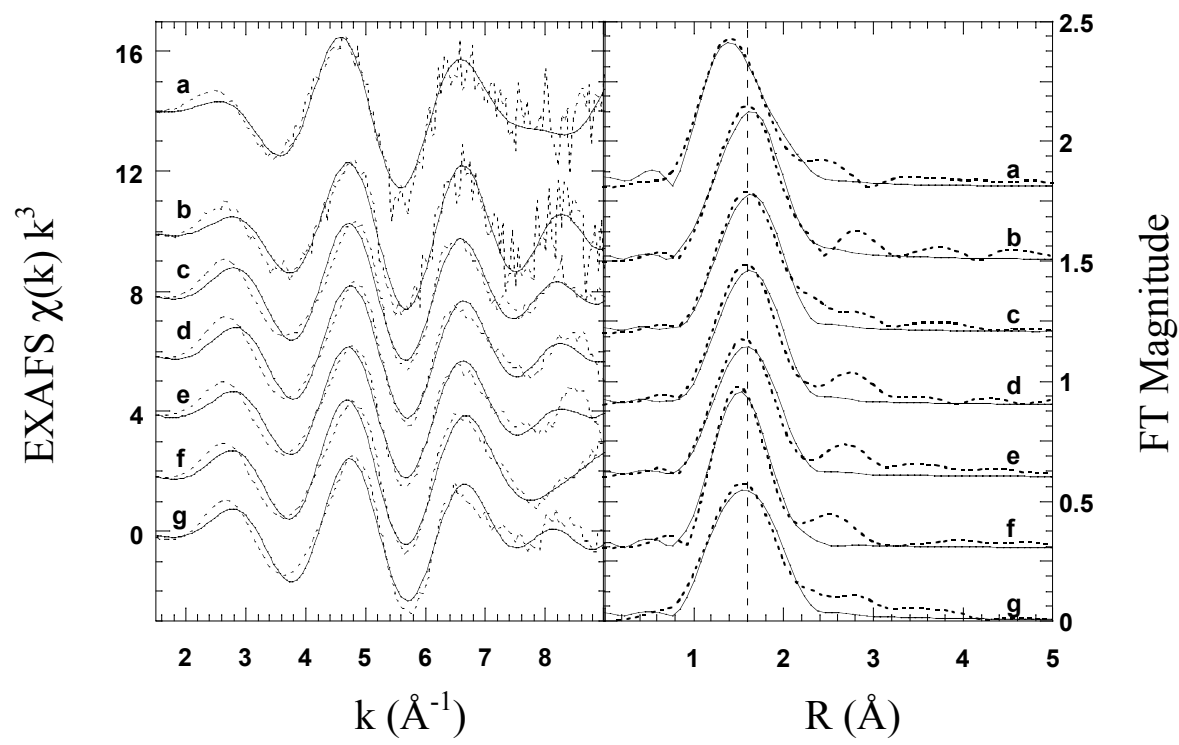

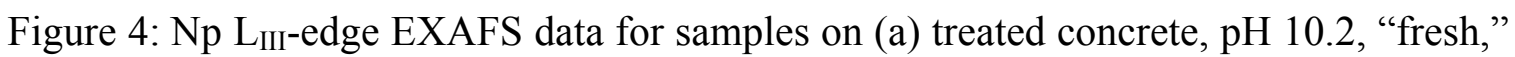
(b) untreated concrete, $\mathrm{pH}$ 12.3, (c) untreated concrete, $\mathrm{pH} 11.3$, (d) untreated concrete, $\mathrm{pH}$ 10.3, (e) treated concrete, $\mathrm{pH}$ 11.3, (f) treated concrete, $\mathrm{pH}$ 10.3, (g) treated concrete, $\mathrm{pH}$ 9.3. The dashed line is the experimental data, and the solid line represents the best theoretical fit to the data. LEFT: raw $\mathrm{k}^{3}$-weighted data. RIGHT: Fourier transforms.

Table II. Np EXAFS curve-fitting results and $\% \mathrm{NpO}_{2}{ }^{+}$.

\begin{tabular}{|c|c|c|c|c|c|c|}
\hline Sample & Shell & $\mathrm{N}^{\mathrm{a}}$ & $\mathrm{R}(\AA)^{\mathrm{a}}$ & $\sigma^{2}\left(\AA^{2}\right)$ & $\begin{array}{c}\% \mathrm{~Np}(\mathrm{~V}) \\
\text { by } \\
\text { XANES fit }^{\mathrm{c}}\end{array}$ & $\begin{array}{c}\text { \% Np(V) by } \\
\mathrm{Np}-\mathrm{O}_{\text {axial }} \\
\text { fraction }^{\mathrm{b}}\end{array}$ \\
\hline \multirow[t]{2}{*}{ Treated concrete, $\mathrm{pH} 9.3$} & $\mathrm{~Np}-\mathrm{O}_{\text {axial }}$ & 0.90 & 1.82 & 0.00300 & \multirow[t]{2}{*}{36.3} & \multirow[t]{2}{*}{45.0} \\
\hline & $\mathrm{Np}-\mathrm{O}$ & 4.4 & 2.39 & 0.00915 & & \\
\hline \multirow[t]{2}{*}{ Treated concrete, $\mathrm{pH} 10.3$} & $\mathrm{~Np}-\mathrm{O}_{\text {axial }}$ & 1.2 & 1.86 & 0.00300 & \multirow[t]{2}{*}{47.6} & \multirow[t]{2}{*}{62.0} \\
\hline & $\mathrm{Np}-\mathrm{O}$ & 5.6 & 2.39 & 0.01535 & & \\
\hline \multirow[t]{2}{*}{ Treated concrete, $\mathrm{pH} 11.3$} & $\mathrm{~Np}-\mathrm{O}_{\text {axial }}$ & 0.85 & 1.85 & 0.00300 & \multirow[t]{2}{*}{44.9} & \multirow[t]{2}{*}{43.0} \\
\hline & $\mathrm{Np}-\mathrm{O}$ & 4.2 & 2.39 & 0.00971 & & \\
\hline \multirow[t]{2}{*}{ Untreated concrete, $\mathrm{pH} 10.3$} & $\mathrm{~Np}-\mathrm{O}_{\text {axial }}$ & 0.71 & 1.84 & 0.00300 & \multirow[t]{2}{*}{37.8} & \multirow[t]{2}{*}{36.0} \\
\hline & $\mathrm{Np}-\mathrm{O}$ & 4.6 & 2.38 & 0.00940 & & \\
\hline \multirow[t]{2}{*}{ Untreated concrete, $\mathrm{pH} 11.3$} & $\mathrm{~Np}-\mathrm{O}_{\text {axial }}$ & 0.74 & 1.84 & 0.00300 & \multirow[t]{2}{*}{38.8} & \multirow[t]{2}{*}{37.0} \\
\hline & $\mathrm{Np}-\mathrm{O}$ & 4.7 & 2.40 & 0.00902 & & \\
\hline \multirow[t]{2}{*}{ Untreated concrete, $\mathrm{pH} 12.3$} & $\mathrm{~Np}-\mathrm{O}_{\text {axial }}$ & 1.0 & 1.86 & 0.00300 & \multirow[t]{2}{*}{45.9} & \multirow[t]{2}{*}{50.0} \\
\hline & $\mathrm{Np}-\mathrm{O}$ & 3.4 & 2.39 & 0.00421 & & \\
\hline \multirow{2}{*}{$\begin{array}{l}\text { Fresh, treated concrete, } \\
\text { pH } 10.2\end{array}$} & $\mathrm{~Np}-\mathrm{O}_{\text {axial }}$ & 1.6 & 1.86 & 0.00300 & \multirow[t]{2}{*}{78.9} & \multirow[t]{2}{*}{77.0} \\
\hline & $\mathrm{Np}-\mathrm{O}$ & 3.4 & 2.44 & 0.00792 & & \\
\hline
\end{tabular}

${ }^{\mathrm{a}}$ The $95 \%$ confidence limits for the bond lengths $(\mathrm{R})$ and coordination numbers $(\mathrm{N})$ for each shell are: Np$\mathrm{O}_{\text {axial }}: \pm 0.004 \AA$ and \pm 0.05 ; Np-O: $\pm 0.003 \AA$ and \pm 0.3 , respectively.

${ }^{\mathrm{b}}$ The $95 \%$ confidence limits for $\% \mathrm{~Np}(\mathrm{~V})$ are $\pm 2.5 \%$ for determination by EXAFS Np- $\mathrm{O}_{\text {axial }}$ fraction and $\pm 7 \%$ for determination by XANES component fitting. 


\section{CONCLUSIONS}

XANES analysis of uranium sorbed onto concrete showed that $\mathrm{U}$ remains as $\mathrm{UO}_{2}{ }^{2+}$. Uranium EXAFS analysis showed that all samples contained a split equatorial shell, which is evidence of inner-sphere surface complexation. Spectra of uranium on hydrothermally treated concrete equilibrated for 5-6 months also contained U-U interactions, signifying oligomer formation or the formation of a surface precipitate. These results suggest that there is a significant change in U-surface structure with concrete hydrothermal treatment.

The Np XANES showed reduction from $\mathrm{NpO}_{2}{ }^{+}$to $\mathrm{Np}^{4+}$, with the amount of reduction observed to increase as a function of equilibrium time. This reduction was determined quantitatively to be $\sim 15 \%$ in the fresh sample and $\sim 50 \%$ in the aged samples. The amount of reduction was observed to be independent of either $\mathrm{pH}$ or hydrothermal treatment of the concrete.

The neptunium EXAFS also showed a reduction of $\mathrm{NpO}_{2}{ }^{+}$to $\mathrm{Np}^{4+}$. Analysis of the $\%$ reduction based solely on the coordination number of the axial oxygen shells yielded results in good agreement with the more rigorous analysis of the XANES region. The absence of Np-Np interactions in the EXAFS spectra provides evidence that neptunium partitioning is controlled by sorption of the $\mathrm{Np}(\mathrm{V})$, followed by reduction, and not by reduction followed by formation of $\mathrm{Np}(\mathrm{IV})$ surface precipitates.

\section{ACKNOWLEDGEMENTS}

This work was performed under the auspices of the U.S. Department of Energy by Lawrence Livermore National Laboratory under Contract W-7405-Eng-48. This work was partly supported by the Yucca Mountain Site Characterization Project at LLNL, and was done (partially) at SSRL, which is operated by the Department of Energy, Division of Chemical Sciences. Additional XAFS experimental support was provided by D. Caulder and W. Lukens and the Actinide Chemistry Group at LBNL

\section{REFERENCES}

1. T. G. Heath, D. J. Ilett, C. J. Tweed, Mat. Res Soc. Symp. Proc. (1996).

2. B. F. Greenfield, D. J. Ilett, M. Ito, R. McCrohon, T. G. Heath, C. J. Tweed, S. J. Williams, M. Yui, Radiochim. Acta 82, 27-32 (1998).

3. M. Atkins, F. P. Glasser, Mat. Res Soc. Symp. Proc. (1990).

4. J. J. Bucher, N. M. Edelstein, K. P. Osborne, D. K. Shuh, N. Madden, P. Luke, D. Pehl, C. Cork, D. Malone, P. G. Allen, Rev. Sci. Instr. 67 (1996).

5. R. Prins, D. E. Koningsberger, Eds., X-Ray Absorption: Principles, Applications, Techniques for EXAFS, SEXAFS, and XANES (Wiley-Interscience, 1988).

6. J. Mustre de Leon, J. J. Rehr, S. Zabinsky, R. C. Albers, Phys. Rev. B 44, 4146-4156 (1991).

7. B. Ravel, "ATOMS, a program to generate atom lists for XAFS analysis from crystallographic data." (University of Washington, Seattle, WA., 1996).

8. J. C. Taylor, H. J. Hurst, Acta Cryst. B 27, 2018-2022 (1971).

9. E. R. Malinowski, Factor Analysis in Chemistry (Wiley-Interscience, 1991).

10. P. G. Allen, D. K. Shuh, J. J. Bucher, N. M. Edelstein, C. E. A. Palmer, R. J. Silva, S. N. Nguyen, L. N. Marquez, E. A. Hudson, Radiochim. Acta 75, 47-53 (1996). 